\title{
El text com a element diferenciador en les obres de Carles Santos ${ }^{1}$
}

\author{
Joaquín Ortells Agramunt (agramunt@edu.uji.es) \\ Universitat Jaume I
}

\section{Introducció}

La música, com a element expressiu, sempre ha estat al servei d'altres elements com el text o les imatges. Només cal fer una passejada per la unió d'aquesta amb les imatges o l'escenografia per a adonar-se'n que la música sempre va ser un element potenciador de l'expressivitat escènica o les imatges. Des de l'antic teatre grec, on els distints instruments i les distintes escales potenciaven la personalitat i el caràcter dels personatges, passant per la utilització de la música «al servei del text i de l'expressivitat» com promulgaven els membres de la Camerata Fiorentina, en l'òpera, seguint amb els estereotips musicals utilitzats en el cine mut i, posteriorment, la composició de les bandes sonores originals, com l'última baula de la cadena de muntatge dels films i/o sèries, la música sempre ha estat «al servei de». Només l'original treball de Walt Disney i Leopold Stokowski, Fantasia, va modificar aquests paràmetres i va anteposar la música a les imatges: aquestes van estar-hi al servei de la primera. Per primera vegada, la música no era un complement potenciador, sinó el guió que s'havia de seguir per a realitzar el treball.

Si unim text i música, observem que els resultats són semblants. Ja ha estat comentat el resultat en l'òpera. A això caldria afegir-hi aquests altres àmbits:

- Els recitals poètics, en els quals, la música acompanya el recitat.

- La musicalització de textos poètics, en els quals la base és el mateix text i la música s'utilitza com a potenciador de l'expressivitat del text.

- Les cançons comercials, en les quals la música, encara que composta alhora que el text, es queda en un segon pla per als oients.

Com un oasi entre tanta submissió queden els lieder, en els quals text i música comparteixen el protagonisme. La música és un complement al text i aquest un complement a la música, queden ambdós components al mateix nivell d'importància.

No s'ha trobat cap obra en la qual la música servisca de fil conductor de la mateixa. Que el text tinga un paper secundari respecte a aquesta és difícil de comprendre. Els compositors, estranyament, es basen en elements no musicals per a la composició.

Aquests paràmetres són així fins a arribar a l'obra de Carles Santos. ${ }^{2}$ El compositor

\footnotetext{
${ }^{1}$ Traducció del Servei de Llengües i Terminologia (UJI).

${ }^{2}$ Pianista i compositor de Vinaròs, deixeble de Joan Brossa i John Cage; la seua obra pot emmarcar-se dins del minimalisme musical i la indeterminació. Compositor resident de la Fundació Joan Miró, ha representat les seues obres escèniques en els festivals musicals més importants d'Europa i Amèrica del Nord. Ha rebut, per aquestes, innombrables distincions i premis per l'originalitat de les seues propostes i el rigor de la seua realització, entre els quals
} 
de Vinaròs posseeix un ampli catàleg compositiu dedicat a la veu i ell mateix afirma categòricament que «el guió de les meues composicions és la música, la partitura». D’aquesta manera cal preguntar-se: Quina funció té el text en l'obra de Santos? És, potser, un element secundari que no aporta o fins i tot resta al component musical? La resposta a aquestes preguntes la donen l'anàlisi i l'audició de les seues obres. Indubtablement, l'obra de Carles Santos, en conjunt, és original. Així doncs, i en referència als seus espectacles escènics, Josep Ruvira, ${ }^{3}$ en el treball Los desafíos artísticos de Carles Santos, afirma (Ruvira, 2008: 39):

[...] resulta más comprensible decir "es un nuevo espectáculo de Santos" que "es una especie de ópera" o que "es una performance de grandes dimensiones en la que cantan o tocan el piano". Consisten estos en concepciones escénico-musicales que se resisten al formato y a los códigos que imponen los géneros tradicionales.

Tenint en compte que l'estètica de Santos ve donada, en gran manera, per la seua fructífera relació amb el poeta català Joan Brossa, a qui considera com a son pare artístic, podem començar a entendre el significat de la veu i la paraula per a Santos en les seues obres. La veu no és només un instrument, sinó un mitjà d'expressió, i la paraula, el text, el mitjà del qual es val. Sempre la música per davant del text. Sempre la música, la partitura, com a fil conductor. Com afirma Ruvira (2008: 42), «las experiencias de Santos con la voz son múltiples y muchas de ellas anteceden a su primera obra grabada».

El text en Santos és un element expressiu de primera magnitud, però sempre s'adequa a la música, que és la seua guia. A això cal afegir-hi l'originalitat amb la qual el mestre de Vinaròs tracta aquest. Però tot això no tindria raó de ser sense fixar les bases de l'obra de Santos. Una sèrie de paràmetres defineixen l'obra del genial compositor castellonenc.

\section{Anàlisi de l'obra instrumental}

Piano, veu, escenari i la resta de les arts. Per a Carles Santos són elements moltes vegades indivisibles $i$, al mateix temps, complementaris.

La seua obra és una obra viva per a l'intèrpret. Pot ser modificada, alterada i combinada, en funció de la situació temporal en què es trobe. És una obra oberta que requereix, moltes vegades, de la musicalitat de l'intèrpret per a la seua execució.

Els fragments repetits lliurement; la velocitat d'execució que s'adapta a l'acústica del moment; la mètrica de les obres, no definida amb exactitud i que ha d'adaptar-se a l'acústica, al públic i a la sensibilitat de l'intèrpret en aqueix moment; la utilització interpretativa per a magnificar un altre tipus d'art que s'executa al mateix temps que la música, en moments determinats. Són tots aquests, elements que fan d'aquesta producció musical un món en constant moviment i progrés.

El llenguatge de l'obra de Santos s'ha catalogat de minimalista. ${ }^{4}$ Després d'observar amb deteniment les seues partitures no hi cap una altra reflexió que posar en dubte aquesta afirmació.

destaquen diversos premis Max, el Premi Nacional de Música i la Medalla d'Or de la Universitat Jaume I de Castelló.

${ }^{3}$ Doctor en Filosofia, alterna la funció docent amb la investigació, fonamentalment cap a l'àmbit de l'estètica musical i especialment sobre les avantguardes artístiques.

${ }^{4}$ Tom Johnson el qualifica com a «minimalista romàntic». 
El seu llenguatge evoluciona, no es modifica; aquesta evolució s'observa en la seua escriptura manuscrita (no es tracta del simple afegit o supressió de notes, sinó del desenvolupament del discurs musical) i a més està en funció del moment en el qual és interpretat.

Pel que fa a la forma musical, les característiques més determinants de la seua obra, reflectides en els seus manuscrits, podrien resumir-se en el següent:

- Utilitza, habitualment, blocs d'escriptura musical per als seus manuscrits.

- En els fulls d'aquests blocs, només escriu en les pàgines senars, deixant les pàgines parelles (o reversos) per a anotacions o canvis. En el cas que allò que s'ha escrit en aquestes pàgines tinga validesa, numera les mateixes amb la mateixa xifra de la pàgina anterior i un Bis.

- Cada grup o motiu és escrit en un pentagrama, per separat.

- Les repeticions no s'assenyalen habitualment com a tals, sinó amb doble barra divisòria al final del motiu a repetir.

- No sol utilitzar el signe de clau en els seus manuscrits. En aquest cas, se sobreentén que «la música escrita està en clau de sol».

- En comptades ocasions els seus manuscrits inclouen referències a la dinàmica a emprar.

- Tampoc són habituals les indicacions agògiques.

- No sol utilitzar el signe de compàs al principi de les seues composicions, encara que s'esbrina per les línies divisòries.

I, sobre tot, per a determinar la influència del text en les seues obres,

- Modifica les seues composicions i les adapta a l'element escènic que les acompanya. Aquestes modificacions sol realitzar-les en fotocòpies dels seus manuscrits, no directament en aquests.

Així doncs, veiem que la seua obra és una obra oberta en tots els sentits i en tots els elements, per la qual cosa un text tancat i eix de les seues composicions no té sentit. El text ha d'adaptar-se a la idiosincràsia de l'obra i aquesta es basa en la llibertat interpretativa a partir de la música i a través de les circumstàncies que conflueixen en el moment exacte d'executar-la. És per això que l'originalitat dels seus textos i, al mateix temps, la força expressiva conviuen amb aquesta llibertat interpretativa. Però, en quin sentit? Com pot el text adaptar-se i modelar-se al moment exacte de l'execució? De quina manera es modifiquen les frases literàries, el significat i el sentit sense que aquestes perden credibilitat?

\section{La veu}

Com hem comentat anteriorment, la veu és un vincle d'expressivitat en l'obra de Santos. Ja des de les seues primeres experiències, el recurs de la veu, més enllà de la utilització habitual en paràmetres escenicomusicals, li atrau enormement i desenvolupa la seua imaginació. Com a exemple citem el film gravat amb Pere Portabella, ${ }^{5}$ en el qual el Cor del Gran Teatre del Liceu realitza una lectura exclusivament rítmica (sense entonació i amb el nom de les notes) d'una partitura de Wagner. Encara que aquest siga un recurs

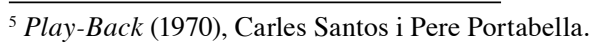


pedagògic habitual en les escoles de música i en els conservatoris, «en la voz de un coro produce un resultado sorprendente con no poca carga humorística» (Ruvira, 2008: 42).

Si es pren com a punt de partida aquest procés, veiem com l'obra de Santos es mou amb naturalitat en els distints processos vocals i l'experimentació que d'aquests en fa atorga un nou significat al que coneixem com a obra vocal (Ruvira, 2008: 42):

Santos propone una utilización de la voz realmente sugerente, a partir de una técnica que llegó a ser bautizada por Jackson McLow como expanding of incremental repetition [...]. Lo importante en esta técnica que ampliará en los fragmentos corales de sus espectáculos será la intensidad expresiva que con ella puede conseguirse.

Així doncs, hi ha un element expressiu a potenciar que és la veu. Però aquesta ja havia estat utilitzada amb anterioritat en el cant i en el recitat. Què pot oferir llavors Santos de nou en la utilització d'aquest recurs? La contestació la dóna el propi Santos (Ruvira, 2008: 43):

¿Por qué cantar? [...] la respuesta es simple [...]: la fisicalidad de la canción. Desde el momento que una voz se desplaza de su habitual campo del habla, el cuerpo cobra energía, cambia la forma de respiración y todo el peso comienza a redistribuirse, a balancearse, a redefinir su gravedad y sus relaciones. [...] Esta es la forma en que se realiza la auténtica comunicación y como la auténtica información se transmite [...]

Però, a més de la veu hi ha un altre element complementari en les seues obres vocals i aquest no és cap altre que el text que acompanya la veu. El text de les obres vocals de Santos no és un text a l'ús. És un text d'acord amb el vehicle que el mostrarà, la veu. És un text al qual l'autor extraurà tot el component expressiu que puga, això sí, atenent-se al motor principal de les seues composicions que no és cap altre que la partitura.

\section{Textos}

El text, en les seues obres, és un altre element més del llenguatge. He de fer constar que Santos atorga una importància vital a la musicalitat dels seus textos. El punt de partida d'aquesta musicalitat és la intenció purament sonora o onomatopeica dels mateixos. Santos desenvolupa «textos cuyo contenido ve desde lo puramente fonético a una construcción discursiva con palabras inventadas, un parloteo fuertemente sugestivo» (Ruvira, 2008: 43). Per a aconseguir aquesta musicalitat utilitza una sèrie d'elements recurrents:

1. Síllabes o paraules inventades per ell. Aquest llenguatge propi busca la força de la paraula i l'impacte en qui l'escolta. Només cal repassar els títols dels seus espectacles o els noms dels seus personatges per a comprendre-ho.

Però, aquestes paraules han d'entendre's unides o separades de l'element melòdic. En cas que no existisca un element melòdic, la música perd el paper protagonista i aquest s'atorga completament al text.

Títols com Katralla ens poden donar una idea del que exposa. Sent una paraula inventada per l'autor, la força expressiva queda patent en el moment de la dicció. A partir de l'element 
estructural de la mateixa (3 síl-labes), el muntatge formal (element musical de gran pes en l'obra de Santos) pren cos a través d'una figuració de tresets enllaçats. El text de referència d'aquesta obra és aquesta paraula i sobre aquesta es desenvolupa tot el discurs musical.

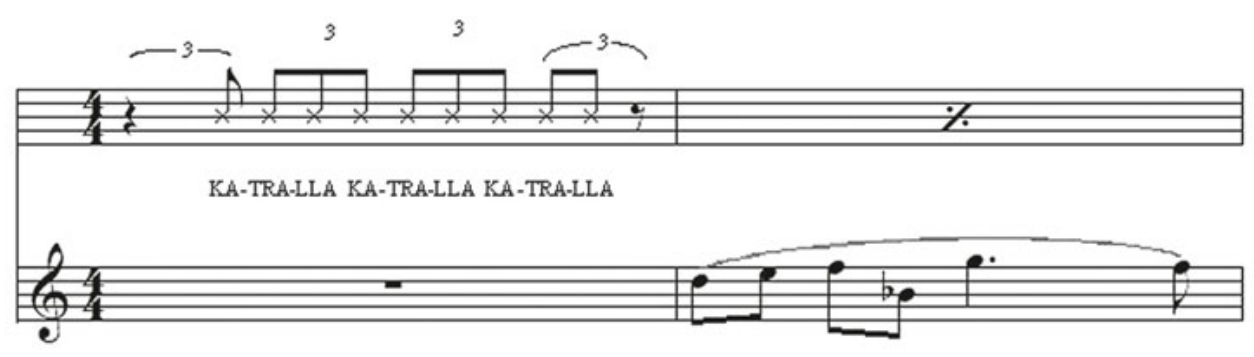

Katralla (Arx 16).

Es pot observar en una altra obra seua el que s'ha exposat anteriorment. És l'obra Tocatico tocatá (1978), que igual que l'anterior, manca d'element melòdic encara que no d'elements expressius. Tornem a trobar un text inventat per l'autor amb gran càrrega expressiva que serveix de base per a la composició. És el primer element textual a presentarse i l'element recurrent al llarg de l'obra. Però aquest element evoluciona, deixa pas a uns altres elements que l'engrandeixen. A aquest es van unint elements expressius com ara onomatopeies o altres síllabes inventades que, si bé en una lectura rasa poden parèixer sense sentit, en el moment que col·loquem les diferències d'altura (sense entonació determinada) marquen unes pautes interpretatives importants. Al mateix temps, la recol·locació d'aquests elements dins del discurs de l'obra, fa d'aquesta un valor viu. No es tracta de la repetició sistemàtica d'elements textuals sinó del seu desenvolupament i adaptació dins d'un tot. Les onomatopeies anteriorment citades (Br, Bom, Pim) s'entrellacen amb síllabes soltes, aparentment sense sentit (Taa, Xac) però en les quals hi ha indicacions de direccionalitat de l'altura musical (cap a l'agut o cap al greu). Encara que aquesta direccionalitat és relativa i no absoluta, ja que l'autor no indica exactament fins a quin punt d'altura s'ha d'arribar en la interpretació.

La velocitat d'execució, les pauses o les repeticions de cada frase s'emmotllaran al moment de l'execució, en funció de paràmetres dispars com la reverberació de la sala, l'estat anímic del públic o del mateix intèrpret, entre d'altres. Això fa que cada interpretació de l'obra siga completament distinta. De totes les que puguen existir, quina és l'adequada segons l'autor? És una pregunta oberta que analitzarem més tard.

Els mateixos paràmetres els trobem en Pepa (1980). Aquesta és la paraula que dóna títol a l'obra i al mateix temps, la que serveix de fil conductor de la mateixa. A aquesta se li uneixen altres (tu, tira, o, chimbamba) alhora que apareixen onomatopeies (uai, ia, pim, ja, br). Així mateix, se'n troben indicacions de direccionalitat vocal en la interpretació que s'afegeixen a aquestes indicacions d'expressivitat en l'execució com «eròtic». Com en l'obra anterior, els paràmetres de velocitat, estat anímic, reverberació, etc., no estan previstos i són aquests els que juguen un paper primordial en les diferents execucions de l'obra ja que aquesta es modifica en funció dels mateixos. 

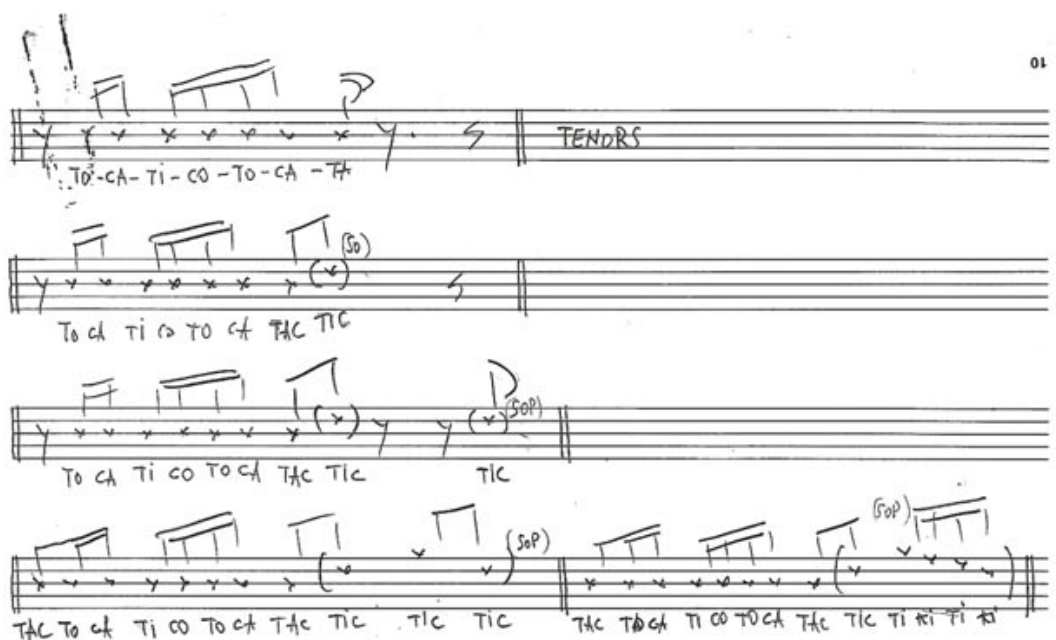

(B)
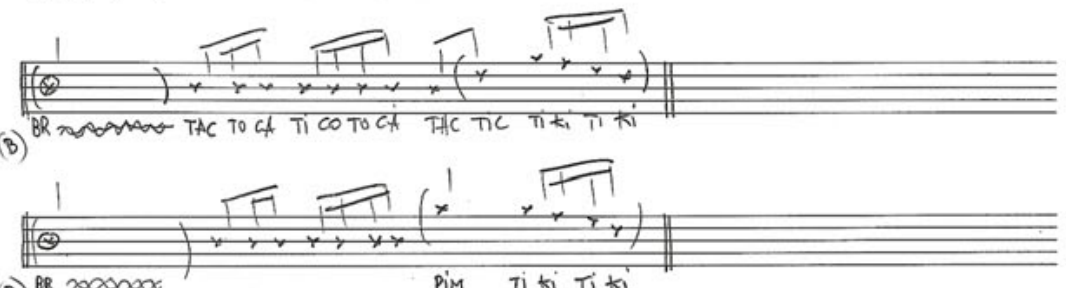

(B) BR 20000000

Pim $T i k i$ Tiki
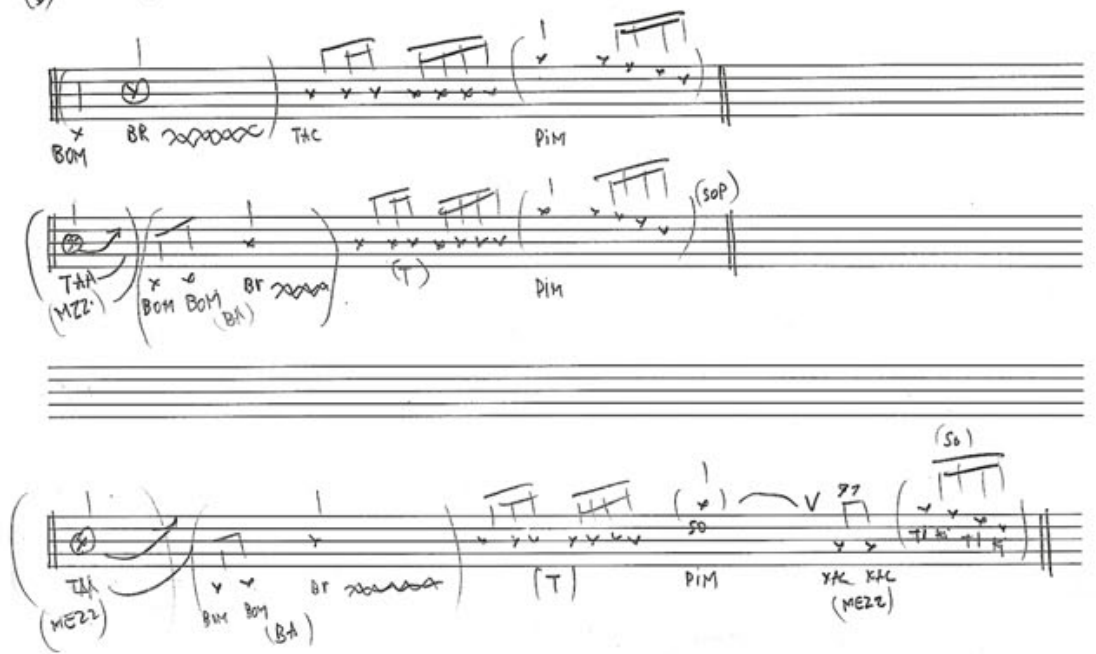


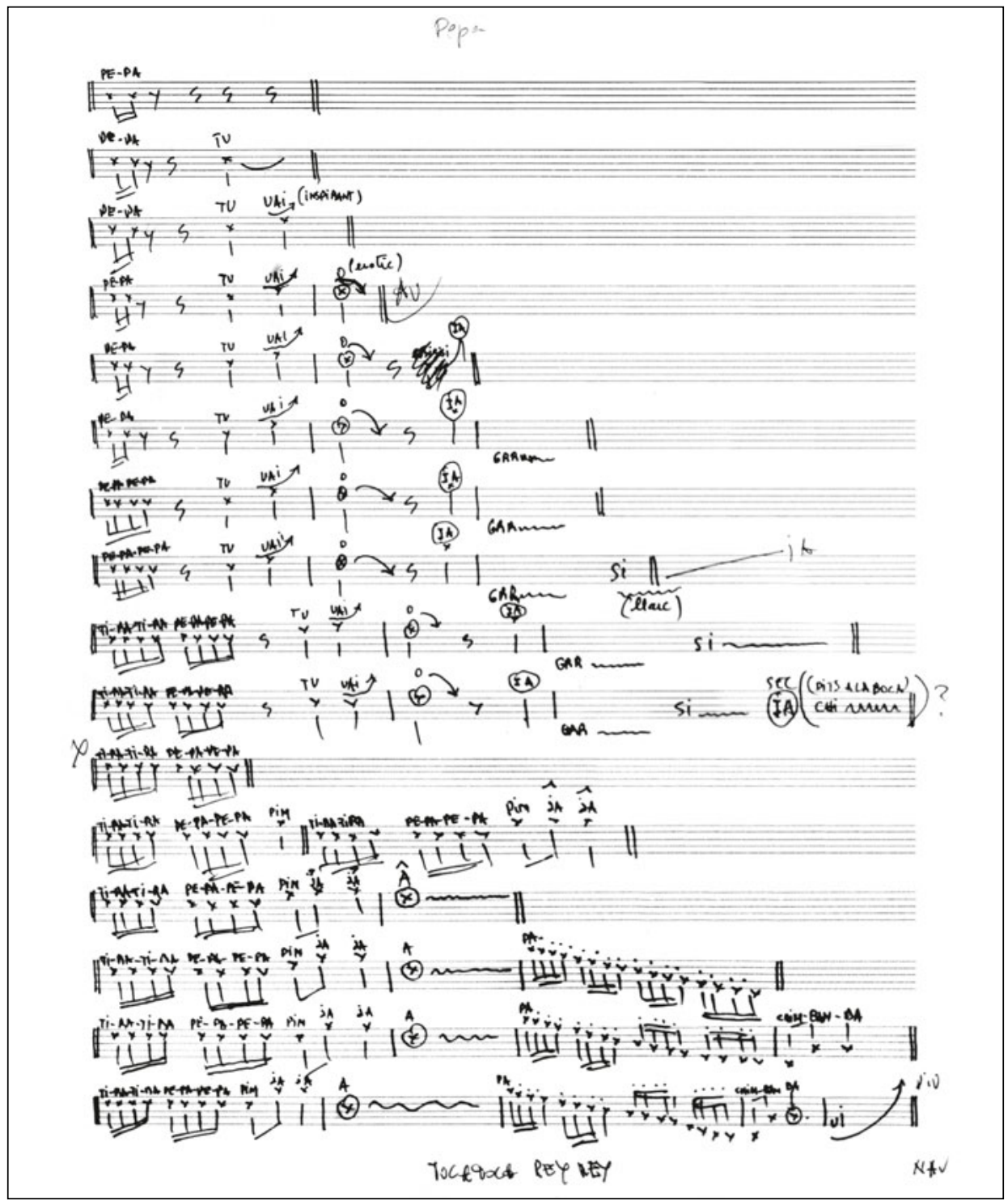

2. En alguns manuscrits de Santos, els textos no contenen referències musicals. Amb això entenem que no hi ha mètrica o altura en aquests.

Les interpretacions que han de realitzar-se dels mateixos és lliure, i atenen a recitats amb càrrega expressiva determinada pel mateix text. El seu contingut segueix les pautes descrites en el punt anterior: paraules inventades i onomatopeies, encara que aquestes en menor grau. És en aquest moment quan l'autor utilitza un recurs que amplia els paràmetres exposats fins ara: extensos textos sense significat, però plens de força, en molts casos, de 
la força de la blasfèmia (DÉU DE DÉU QUE XUFLEGUES LA MARMOLLA VURIDALL DE CONFLEXIONS RULLERIES I MELASSES [...] (Ricardo i Elena, 2000)). És en aquests amplis textos on les referències a la religió i al sexe són més habituals. I és en aquests textos on trobem la descomposició fonètica de les paraules per a convertir en abstracte l'estrat simbòlic de la llengua. Gran part d'aquest recurs és utilitzat en les seues composicions escèniques, composicions d'un major calat expressiu, atesos els recursos escènics que s'hi poden utilitzar i que permeten una major càrrega expressiva del text.

3. Existència de referències musicals, però no de referències literàries. En aquest cas, els cantants han de pronunciar la vocal de la nota exposada antecedida, generalment de la consonant $l$ (lo, le, li, la lo, la, li). ${ }^{6}$

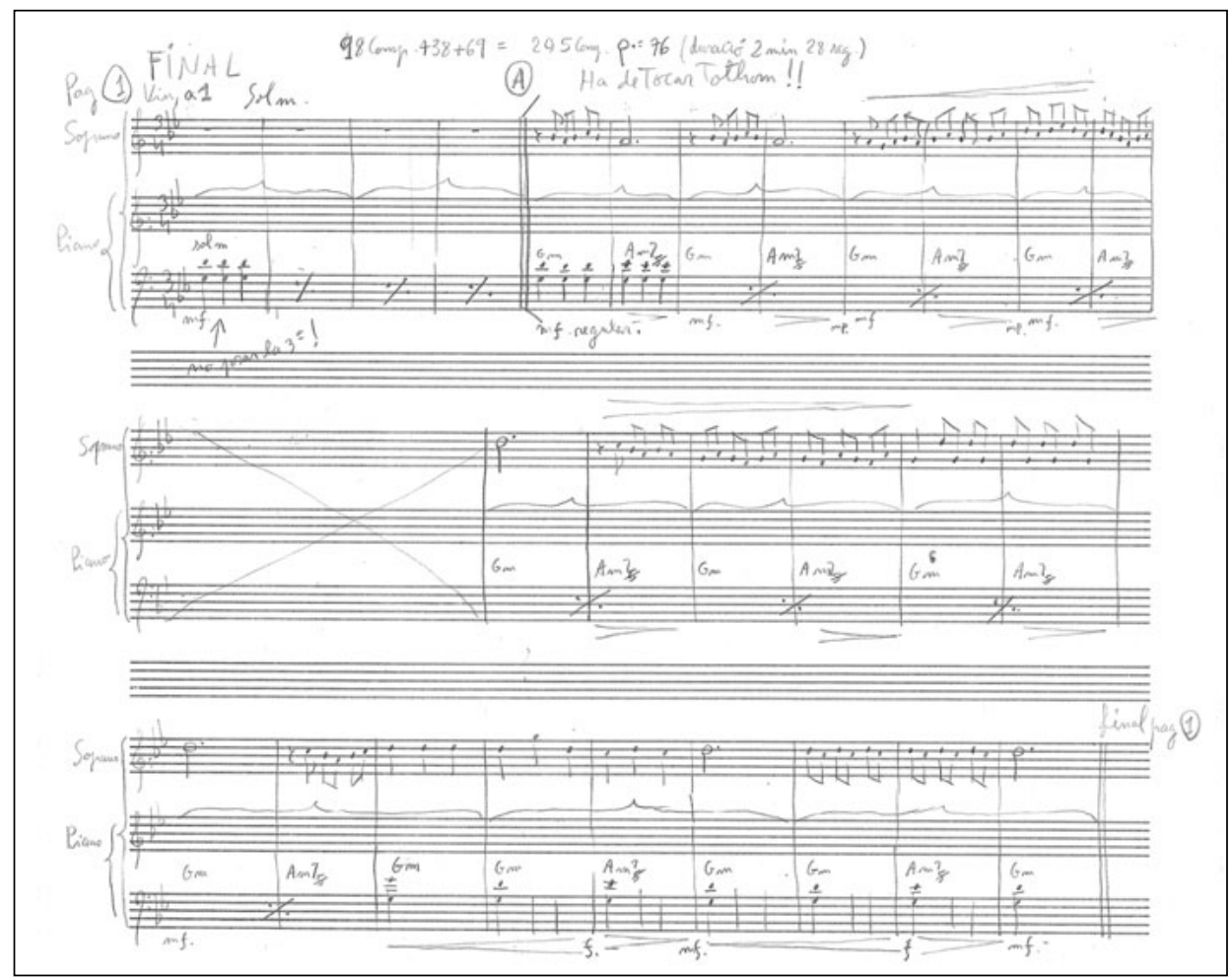

És el cas contrari al punt anterior. Hi ha música, però no hi ha text. Com pot interpretarse una obra vocal sense cap referència al text a utilitzar? L'exemple clar d'aquest estil el trobem en la seua obra Promenade Concert, també coneguda com Concert Toni Mira, ${ }^{7}$

\footnotetext{
${ }^{6}$ Es pot apreciar aquest fet en la gravació realitzada en directe, el dia de l'estrena, de l'obra Promenade Concert. El text pronunciat per la soprano no consta en el seu manuscrit. Aquesta obra va ser estrenada el 20 d'abril de 1993, a la Fundació Joan Miró, amb motiu de la inauguració de l'exposició Joan Miró 1893-1993.

${ }^{7}$ Amb aquest títol assenyala l'autor l'obra, en la coberta del bloc d'escriptura musical en el qual es troba el manuscrit.
} 
en la qual, en el manuscrit de l'autor consta un pentagrama dedicat a la veu en què trobem referències musicals (altura i mètrica) però no té text. En la gravació realitzada el dia de l'estrena (CD DBL 38696-93) observem el que s'ha dit abans: el text interpretat per la soprano consta de les vocals de les notes escrites, les quals van antecedides de la consonant $l$ en la majoria de la gravació.

Encara que hi ha un referent gravat d'allò que desitja l'autor, en cap moment en els seus manuscrits fa referència a què i com ha d'interpretar-se. En una de tantes entrevistes que se li han fet, en ser preguntat per aquest fet, Santos va defensar, com tantes altres vegades, la llibertat d'interpretació. No va exposar ni va defensar allò que s'ha mostrat en la gravació, com la fórmula per a interpretar els seus textos no escrits. Com ell mateix defensa sempre sobre la seua obra, «la interpretació és tan lliure com l'intèrpret la puga defensar».

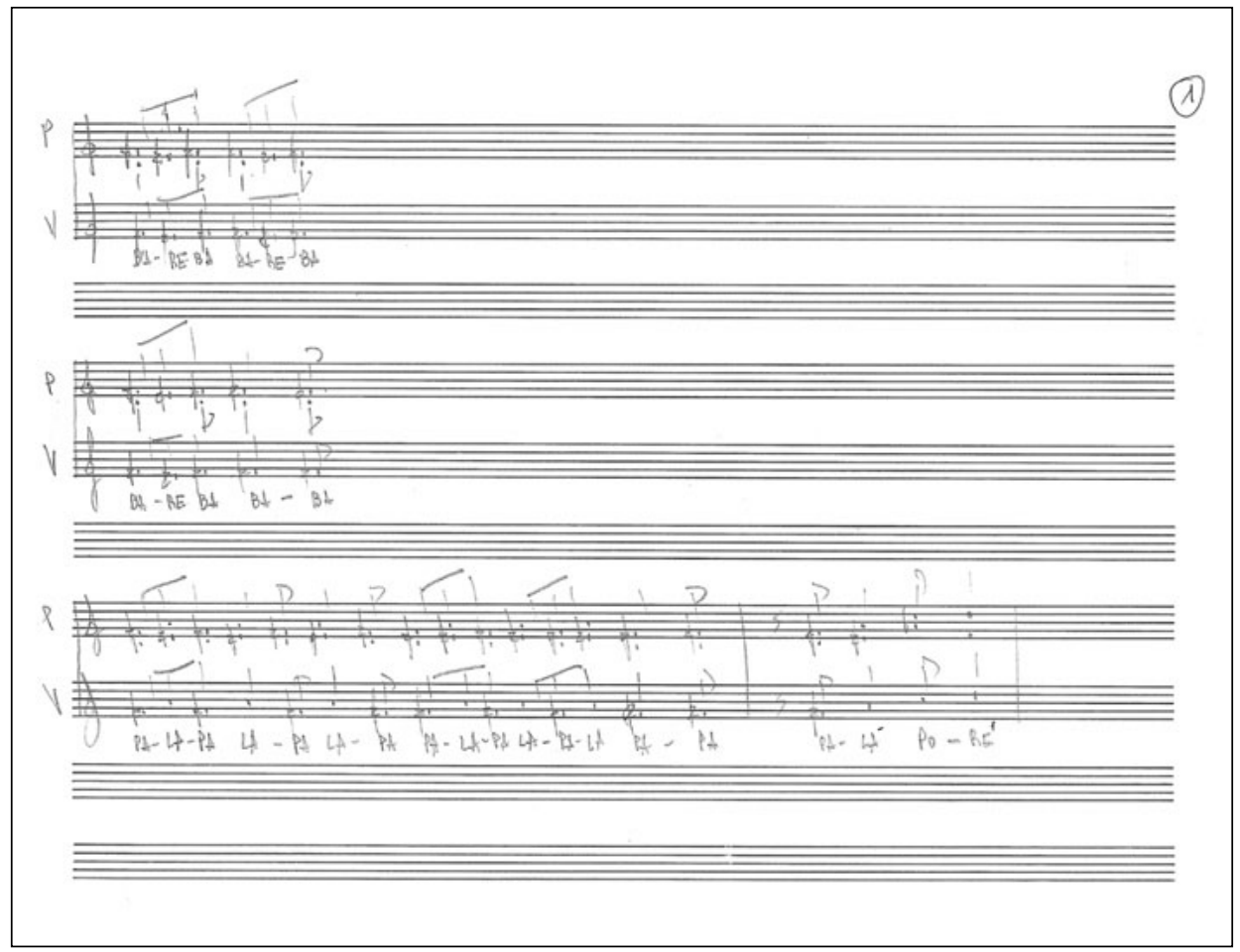

4. Existència de tots els paràmetres necessaris i utilitzats habitualment en les composicions vocals.

Encara que és el més habitual en qualsevol composició vocal, no ho és tant en l'obra de Santos. Els recursos utilitzats continuen sent els mateixos que s'han tractat en aquest treball (paraules inventades, onomatopeies, etc.), però en aquest cas estan col-locats en els seus manuscrits com és habitual en les partitures a l'ús: mètrica, altura i concordança sil·làbica. Com a exemple d'aquest estil compositiu, presentem una obra inèdita de l'autor, escrita per a veu (sense identificar) i piano. 


\section{Interpretació}

Amb anterioritat ens formulàvem la pregunta: Quina interpretació d'una obra de Santos és la més adequada, segons l'autor? Per a contestar a aquesta pregunta s'ha de tindre en compte, ja per a començar, el pensament de Santos. Hauríem de dir pensaments, en plural, ja que aquests són diversos. Passem a enumerar:

- Santos sempre ha estat poc favorable a les gravacions de les seues obres. Poques són, verdaderament, les gravacions de les obres de Carles Santos disponibles. A pesar de registrar els seus treballs en una sèrie de discos, és difícil tornar a trobar una gravació diferent de la seua obra. Possiblement la causa siga que ha estat el propi autor l'executant de les seues obres. Atès que majoritàriament no estan publicades o editades, no estan a l'abast d'un públic interpretatiu majoritari.

- Santos considera la seua obra un element viu i no estanc, per la qual cosa no li agrada donar més indicacions de les necessàries per a la interpretació de les seues peces. Així, deixa llibertat a l'executant per a interpretar, com considere adequat, les obres de l'autor. Això dóna peu a què les execucions de les obres de Santos, realitzades per altres instrumentistes, siguen completament dispars unes d'altres. L'executant ha de buscar en el discurs musical, el sentit interpretatiu de cada moment i adaptar-lo a les circumstàncies que sobreviuen en aqueix mateix instant.

Per tot això, parlar d'interpretació en l'obra de Santos és parlar de llibertat. La llibertat de l'executant que es converteix en intèrpret en el moment en què es fa amo de l'obra i pot adaptar-la a les seues inquietuds i pensaments. Per tant, no hi ha una única interpretació de les obres de Santos. Hi ha tantes com vegades són executades.

\section{BIBLIOGRAFIA}

García, J.M. i M. Rom (1982): Finestra Santos, Barcelona, Cineclub Associació d'Enginyers Industrials de Catalunya.

Guerrero, M. (2006): Carles Santos, Visca el Piano!, Barcelona, Fundació Joan Miró.

Lluís I Falcó, J. (2001): El cinema, Història de la Música Catalana, Valenciana i Balear, vol. viI, Barcelona, Edicions 62.

Ruvira, J. (1996): El caso Santos, València, Mà d'obra.

- (2008): Los desafíos artísticos de Carles Santos, València, Institució Alfons el Magnànim.

\section{WEBGRAFIA}

$<$ http://usuarios.multimania.es/compositores/csantos00.html> (4 de setembre de 2011) $<$ http://usuarios.multimania.es/compositores/csantos01.html> (4 de setembre de 2011) $<$ http://usuarios.multimania.es/compositores/csantos04.html> (4 de setembre de 2011) $<$ http://usuarios.multimania.es/compositores/JLLF.html> (4 de setembre de 2011) $<$ http://www.madridteatro.eu/teatr/entrevistas/entrevista059.htm> (4 de setembre de 2011) 
$<$ http://www.madridteatro.eu/teatr/musica/musica003.htm> (4 de setembre de 2011)

$<\mathrm{http} / / /$ www.madridteatro.eu/teatr/informacion/informacion105.htm > (4 de setembre de 2011)

$<$ http://www.tradebit.com/filedetail.php/119346993-voice-tracks > (4 de setembre de 2011)

<http://www.inventodeldemonio.es/2011/04/carles-santos-el-cine-experimental-hace-sus-deberes. html>

(4 de setembre de 2011)

$<$ http://www.tradebit.com/filedetail.php/119346993-voice-tracks> (4 de setembre de 2011)

$<$ http://blogs.periodistadigital.com/arte.php/2007/11/09/p125913> (4 de setembre de 2011)

\section{BIONOTA}

\section{Joaquín Ortells Agramunt}

Nascut a Benicàssim (Castelló), realitza els seus estudis musicals al C. S. de Música de València, on obté les titulacions superiors en Direcció d'Orquestra, Composició i Orquestració, Musicologia i Clarinet, així com el títol de professor de solfeig. Les seues composicions han estat premiades en diferents certàmens i concursos. Ha dirigit més de 300 concerts i ha rebut diversos premis. El seu treball d'investigació «Análisis i catalogación de la obra instrumental de Carles Santos», com a membre del grup d'investigació Patrimoni Musical de Castelló, li serveix d'inici per a la seua tesi doctoral. Pertany, per oposició, al cos de professors d'Ensenyament Mitjà des de 1990 i és professor de música a la Universitat Jaume I de Castelló des de 1998. 